\title{
Blue-green light effects on light-limited rates of photosynthesis: relationship to pigmentation and productivity estimates for Synechococcus populations from the Sargasso Sea
}

\author{
B. B. Prézelin ${ }^{1 *}$, H. E. Glover ${ }^{2}$, B. Ver Hoven ${ }^{1}$, D. Steinberg ${ }^{1}$, H. A. Matlick ${ }^{1}$, \\ O. Schofield ${ }^{1}$, N. Nelson ${ }^{1}$, M. Wyman ${ }^{3}$, L. Campbell ${ }^{4}$ \\ ${ }^{1}$ Department of Biological Sciences and Marine Science Institute, University of California, Santa Barbara, California 93106 , \\ USA \\ ${ }^{2}$ Bigelow Laboratory for Ocean Sciences, West Boothbay Harbor, Maine 04575, USA \\ ${ }^{3}$ Department of Biological Sciences, University of Warwick, Coventry CV4 7AZ, United Kingdom \\ ${ }^{4}$ Department of Oceanography, University of Hawaii, Honolulu, Hawaii 96822, USA
}

\begin{abstract}
The impact of blue-green light incubation on short-term diurnal, daily, and integrated water column estimates of whole water $(>0.2 \mu \mathrm{m})$ and Synechococcus-specific photosynthesis was assessed throughout the euphotic zone at 2 stations in the Sargasso Sea. Replicate samples were incubated under both tungsten white light and broad band blue-green light, where the latter simulated light quality within the upper water column of the open sea. Diurnal variations in size-fractioned $(0.2-0.6 \mu \mathrm{m}, 0.6-1 \mu \mathrm{m}$, and $1-5 \mu \mathrm{m})$ blue-green vs white light photosynthesis-irradiance (P-I) curves, chlorophyll (Chl) and phycoerythrin (PE) concentrations, and cell abundance of PE-rich cyanobacterial Synechococcus spp. and Chl-fluorescing algae, were measured within samples from the surface, PE maximum, Chl maximum, and the base of the euphotic zone. Synechococcus spp. dominated ultraphytoplankton communities down to the light depths of the PE maximum ( 3 to $7 \%$ surface illumination, $\mathrm{I}_{\mathrm{o}}$ ), with maxima in cell abundance routinely located at light depths $\geq 50 \% \mathrm{I}_{\mathrm{o}}$. Blue-green and white light incubation conditions generally did not affect light-saturated rates of photosynthesis $\left(\mathrm{P}_{\max }\right.$ ) but blue-green light routinely did provide much higher estimates of light-limited rates of photosynthesis (alpha). For size-fractioned subpopulations dominated by Synechococcus spp., blue-green light values of alpha were $\geq 5$-fold greater than white light estimates. Compared to white light estimates, bluegreen light estimates of total $(>0.2 \mu \mathrm{m})$ daily integrated water column primary productivity were 6 to $13 \%$ higher, while the contribution of Synechococcus spp. to overall primary production rose from between 57 and $61 \%$ to between 73 and $84 \%$. From the surface down to about $5 \% \mathrm{I}_{0}$, the PE content of Synechococcus cells increased with decreasing light and/or increasing inorganic nitrogen availability. Increases in Synechococcus PE/cell occurred in direct proportion to blue-green light measurements of photosynthetic quantum efficiency, further indicating that these cyanobacteria are physiologically well suited to harvest photosynthetically utilizeable light throughout a large portion of the euphotic zone.
\end{abstract}

\section{INTRODUCTION}

Estimates of primary production in oceanic water masses have been revised upward as knowledge of the abundance and activity of very small $(<3 \mu \mathrm{m})$ ultraphytoplankton has advanced during the last decade and field approaches to measuring photosynthetic rates have improved (Glover 1985, Joint 1986, Li 1986. Waterbury et al. 1986, Marra \& Heinemann 1987, Smith

\footnotetext{
- Addressee for correspondence
}

(c) Inter-Research/Printed in F. R. Germany et al. 1987). As a result, the primary productivity of oceanic central gyres now appears to be based largely on the photosynthetic activity of ultraphytoplankton communities (Glover 1985, Fogg 1986, Joint 1986, Li 1986, Shapiro \& Guillard 1986, Waterbury et al. 1986, Li \& Platt 1987). Ultraphytoplankton are more abundant than net-phytoplankton in these oligotrophic environments (Murphy \& Haugen 1985, Glover et al. 1988a, b, Iturriaga \& Marra 1988), perhaps in part because photosynthetic activity of smaller phytoplankters is favored by warmer temperatures found in tropical 
water masses (Malone 1980), they have neglible sinking rates (Malone 1980, Takahashi \& Bienfang 1983) and surface communities may be sustained by nanomolar levels of nitrate (Glover et al. 1988a). Furthermore, oceanic ultraphytoplankton can have near maximal rates of in situ growth (Campbell \& Carpenter 1986, Prezelin et al. 1987C, Iturriaga \& Marra 1988), which could lead to vertical stratification and accumulation of distinct ultraphytoplankton communities at different euphotic zone depths of relatively stable water columns.

There are both prokaryotic and eukaryotic photoautotrophs within ultraphytoplankton communities sampled from oceanic water masses (Murphy \& Haugen 1985). The prokaryotic component is dominated by phycoerythrin-rich (PE) cyanobacterial Synechococcus spp. (Glover 1985, 1988a, b, Murphy \& Haugen 1985, Fogg 1986, Joint 1986, Li 1986, Shapiro \& Guillard 1986, Waterbury et al. 1986, Li \& Platt 1987) and $\mathrm{Chl} b$-containing free-living relatives of Prochloron (Chisholm et al. 1988). The eukaryotic ultraphytoplankton are often represented by a variety of prasinophytes, prymnesiophytes, chrysophytes and cryptophytes (Thomsen 1986). At present, it appears that Synechococcus populations are responsible for the majority of water column productivity in the open sea (Glover 1985, Fogg 1986, Joint 1986, Shapiro \& Guillard 1986, Waterbury et al. 1986, Li \& Platt 1987) and that the vertical distribution of these cyanobacterial populations differs distinctly from that of other photosynthetic ultraphytoplankton populations within the same water column (Murphy \& Haugen 1985, Olsen et al. 1985, Glover et al. 1986, 1988b; Chisholm et al. 1988, Li \& Wood 1988).

During summer, communities of Prochloron-like and eukaryotic ultraphytoplankton are generally more abundant at and below the deep chlorophyll maximum (Chl max) (Glover 1985, Murphy \& Haugen 1985, Glover et al. 1986, Chisholm et al. 1988, Glover et al. 1988 b), where they are thought to be photoadapted to low intensity blue-violet light (Wood 1985, Glover et al. 1987) and/or exploiting the upward advection of nutrients across the thermocline (Glover 1985). From the Chl max down, a decline in both cell abundance and cellular rates of photosynthesis by Synechococcus spp. generally are observed (Glover et al. 1986, 1988b, Prézelin et al. 1986). The decline may be linked to the very low photosynthetic quantum efficiency these cyanobacteria have for absorbed light at wavebands in the blue-violet portion of the visible spectrum, where their cell absorption is dominated by nonphotosynthetic carotenoids (Lewis et al. 1986, Boucher et al. unpubl.). In contrast, Synechococcus spp, are often are order of magnitude more abundant in the upper euphotic layer of the mid-Atlantic than all size categories of
Chl-fluorescing cells combined (Murphy \& Haugen 1985, Glover et al. 1986, 1988a, b, Li \& Wood 1988). Possible explanations for the predominance of Synechococcus over eukaryotic algae in the upper part of the euphotic zone include lower selective grazing pressure on the cyanobacteria, a higher efficiency in utilizing nanomolar levels of inorganic nitrate (Glover et al. 1988a), and/or higher efficiency in utilizing the blue-green spectral bands (500 to $550 \mathrm{~nm}$ ) dominating the underwater light field of the upper mixed layer (Wood 1985, Lewis et al. 1986, Glover et al. 1987. Campbell \& Iturriaga 1988, Li \& Wood 1988, Boucher et al. unpubl.).

Further improvements in predicting ocean primary production will come, in part, from a better understanding of the bio-optical interactions that influence the temporal/spatial distribution and activities of the major photosynthetic components within the ultraphytoplankton communities. Given that mixed community assemblages are routinely sampled in the field, shipboard determinations of metabolic rates for specific phytoplankton subpopulations can be very difficult. However, methodological advances have enabled us to combine selective size fractionation, epifluorescence microscopy, Chl and PE quantification, and small volume radiolabelling techniques in the present study, in order to detail the photophysiological characteristics and photosynthetic activities of Synechococcus subpopulations in a manner usually restricted to laboratory studies of clonal isolates. As part of a larger effort to determine the environmental variables that influence the natural distribution of Synechococcus, the present field study was carried out to assess the impact bluegreen light incubation conditions can have on shortterm diurnal, daily, and integrated water column estimates of whole water $(>0.2 \mu \mathrm{m})$ and on Synechococcus-specific primary productivity. Bluegreen light conditions simulated light fields in the upper euphotic zone and included the absorption waveband of phycoerythrin (PE), which has been shown in carbon action spectra measurements to drive a major fraction of photosynthetic activity in Synechococcus spp. (Lewis et al. 1986, Boucher et al. unpubl.). For temporal and spatial replication, measurements of photophysiological variables were repeated at 3 intervals between dawn and dusk throughout the euphotic zone at 2 stations in the Sargasso Sea. By epifluorescence microscopic enumerations of Chl- and PE-fluorescing components within size-fractioned samples, we were able to compare the effect that bluegreen and white light incubations have on estimates of water column primary productivity and the increased contribution that Synechococcus spp. make to that production. Furthermore, it was possible to relate the relative blue-green photosynthetic light quantum effi- 
ciency of Synechococcus spp. to cellular concentrations of phycoerythrin in field populations sampled throughout the euphotic zone of the Sargasso Sea.

\section{METHODS}

The study was conducted at 2 stations in the Sargasso Sea during summer 1986, working from the RV 'Endeavor'. Stn 1 was occupied between 21 and 28 July and was located $140 \mathrm{~km}$ east of Bermuda. Stn 2 was occupied between 2 and 9 August and was located $165 \mathrm{~km}$ north-northwest of Bermuda (Table 1). An $180 \mathrm{~m}$ submersible pumping system was constructed to collect discrete water samples and to simultaneously profile the vertical distribution of temperature, in vivo chlorophyll (Chl) fluorescence and in situ scalar irradiance (Biospherical Design). Intake hose diameter was 2" $(5 \mathrm{~cm})$ (ID), minimizing shear effects on phytoplankton communities and giving radiolabel uptake rates equivalent to those measured when replicate samples were collected from GoFlo bottles (Prézelin \& Glover unpubl.). Pump flow rate approximated $30 \mathrm{gal}$ (1131) $\mathrm{min}^{-1}$, with a hose transit time of about 3 min from intake to outlet into a darkened container (10 gal [38l], turnover time of $20 \mathrm{~s}$ ) on deck where samples were debubbled. A portion of the debubbled pump effluent was directed via a sumbersible pump (Little Giant 2E-38N) through a secondary debubbler (1 l) and into an adapted Turner designs fluorometer to measure in vivo $\mathrm{Chl}$ fluorescence. Analog data from the fluorometer, in situ light, temperature and depth probes, as well as from a surface quantum irradiance sensor (Biospherical Design) were recorded on strip charts.

Just prior to passage through the fluorometer, $125 \mathrm{ml}$ unfiltered samples were collected from a linetap directly into prewashed $125 \mathrm{ml}$ polyethylene bottles and frozen for subsequent onshore analyses of inorganic nutrient concentrations. Nitrate concentrations in the upper $60 \mathrm{~m}$ were measured using a chemiluminescence technique with a precision of $\pm 2 \mathrm{nM}$ (Garside 1982). At deeper depths, nitrate, nitrite and ammonia concentrations were determined by standard colorimetric methods with precisions of $\pm 0.08,0.01$ and $0.02 \mu M$ respectively (Strickland \& Parsons 1972).

Larger-volume samples were collected directly from debubbled pump effluent in the darkened deck container and placed in darkened 201 polyethylene carboys that were immediately transported inside to the laboratory for analyses. Shipboard enumeration of PEfluorescing Synechococcus spp. and Chl-fluorescing algae were carried out by direct count epifluorescence microscopy, following procedures identical to those detailed by Glover et al. (1986).

For determination of Chl a concentration, duplicate water samples were filtered, with the chosen volume $(50 \mathrm{ml}$ to 11$)$ depending upon the in vivo Chl fluorescence signal from the pump profile and on the filter pore size. Replicate samples were filtered through

Table 1 Physical and chemical characteristics of sampling depths at 2 stations in the Sargasso Sea in summer 1986 . Data are provided for samples used for measuring photosynthetic characteristics. PE max: depth of maximum uncoupled in vivo phycoerythrin fluorescence intensity per $\mathrm{m}^{3}$; $\mathrm{Chl}$ max: depth of maximum in vivo chlorophyll a fluorescence intensity per $\mathrm{m}^{3}$

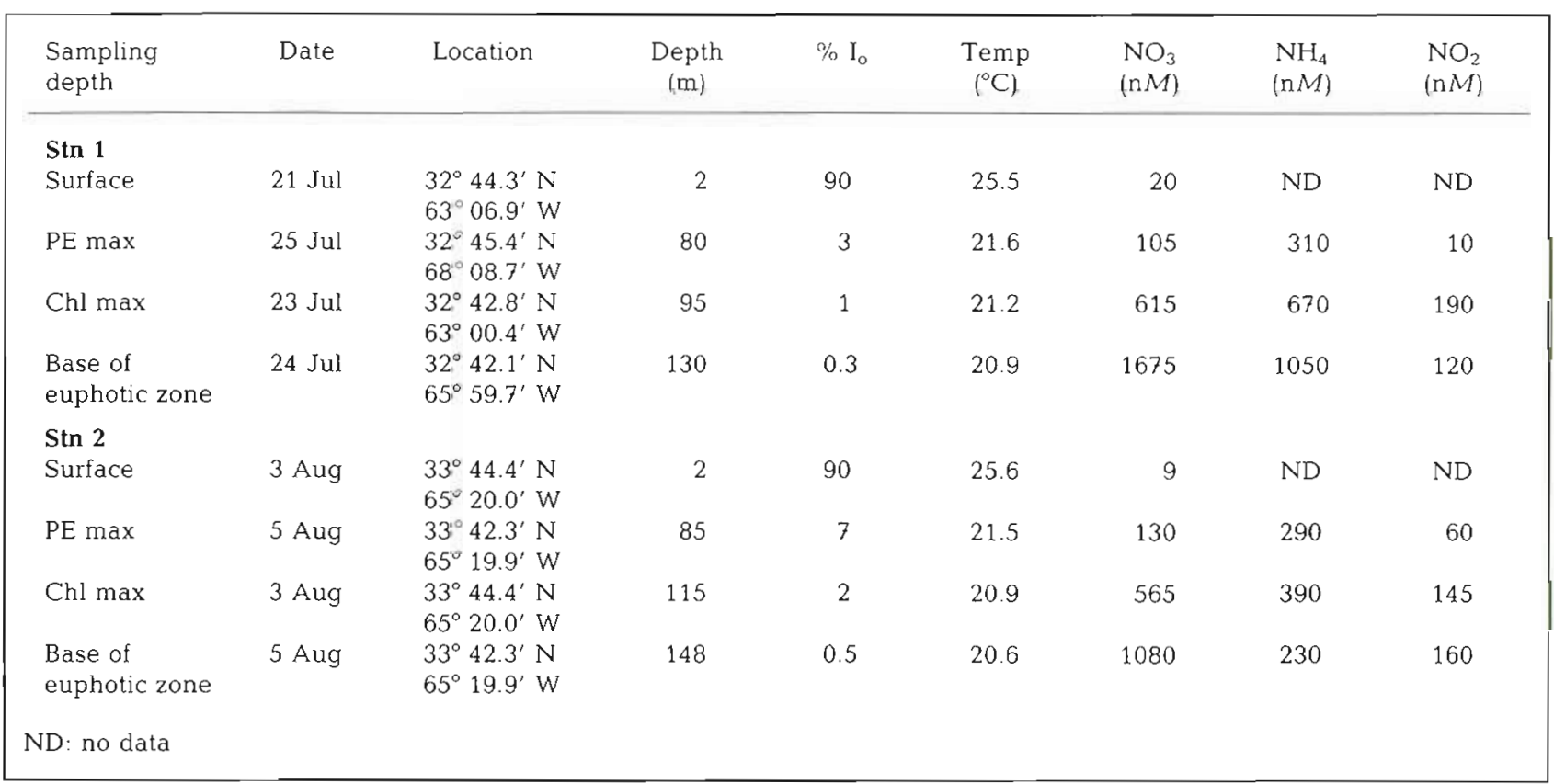


Nuclepore filters of 5, 1, 0.6 and 0.2 um pore sizes. Methods of filtration and extraction were previously described (Glover et al. 1986). Chl concentrations were determined directly for $>5,>1,>0.2 \mu \mathrm{m}$ communities, and by mathematical subtraction for $0.2-0.6 \mu \mathrm{m}, 0.6-1$ $\mu \mathrm{m}$, and 1-5 $\mu \mathrm{m}$ fractions. Standard errors for chlorophylls were routinely less than $10 \%$ of the mean. Cell-specific Chl concentrations in pure $0.6-1 \mu \mathrm{m}$ Synechococcus populations (95 to $100 \%$ of all autofluorescent cells), were used in conjunction with cell numbers in the $1-5$ and $0.2-0.6 \mu \mathrm{m}$ fractions, to estimate Synechococcus $\mathrm{Chl}$ in these other size ranges. The quantity of other algal $\mathrm{Chl}$ in $1-5$ and $0.2-0.6 \mu \mathrm{m}$ fractions could then be calculated by substraction of the amount of Synechococcus Chl from the total concentration in each size category. It was only at the Chl $\max$ and the $0.5 \%$ light depth that the $0.6-1 \mu \mathrm{m}$ fraction could not be considered a pure population of Synechococcus, since they represented $<50 \%$ of autofluorescing cells in this size range. At these depths, we could only estimate cellular Chl concentrations of Synechococcus spp. by proportion, using relative numbers of Synechococcus: algal cells within the $0.6-1 \mu \mathrm{m}$ fraction. Synechococcus $\mathrm{Chl}$ may therefore have been overestimated at the base of the euphotic zone, since algae in this size range are believed to contain more Chl per cell than Synechococcus spp. (Glover et al. 1987).

Phycoerythrin (PE) concentrations were determined using a modification of procedures outlined by Wyman et al. (1985). Synechococcus cells were collected on $0.6 \mu \mathrm{m}$ Nuclepore filters and resuspended in 4 to $5 \mathrm{ml}$ of $50 \%$ glycerol, which uncouples energy transfer between phycoerythrin and phycocyanin. Cell numbers in resuspensions were determined by shipboard epifluorescence microscopy as previously described (Glover et al. 1986). PE was excited at $520 \mathrm{~nm}$ and the in vivo fluorescence emission of the pycoerythrobilin (PEB) chromophores detected at 577 nm (half bandwidth of $4 \mathrm{~nm}$ ) in a Turner 111 fluorometer equipped with enhancer gates to increase sensitivity. The fluorescence intensity of the uncoupled PE in the natural communities was calibrated at sea against similarly treated whole cells of oceanic Synechococcus clone WH7803 of known PE content and against isolated phycobilisomes and purified phycoerythrin from the same organism. The purpose of using phycobilisomes and PE is to check for the amount of quenching resulting from 'package' effects in whole cells. Since the effective concentration of PE localized in cells is high, there will always be a loss of emission intensity owing to quenching and reabsorption. In vivo fluorescence intensity in suspensions of uncoupled cells was linear over the range 0 to $550 \mathrm{ng} \mathrm{PE} \mathrm{ml}^{-1}$.

Diurnal measurements of photosynthesis-irradiance (P-I) relationships were conducted at 4 depths at both stations. Following vertical profiling of the water column, samples were collected at dawn, midday and dusk from the surface, the depth of the uncoupled PE $\mathrm{m}^{-3}$ fluorescence maximum, the depth of the in vivo Chl fluorescence maximum and the base of the euphotic zone $\left(0.3\right.$ to $0.5 \% \mathrm{I}_{\circ}$ ) (Table 1$)$. Unfiltered whole water samples were inoculated with sodium ${ }^{14} \mathrm{C}$-bicarbonate ( 3 to $5 \mu \mathrm{C} \mathrm{ml}^{-1}$ final activity) and 15 to $17 \mathrm{ml}$ aliquots dispensed into acid-washed glass scintillation vials, following procedures detailed in Prezelin et al. (1986, 1987b). Each P-I curve represented 14 light samples (measured at irradiances up to $550 \mu \mathrm{E} \mathrm{m}^{-2} \mathrm{~s}^{-1}$ in white light; up to $200 \mu \mathrm{E} \mathrm{m}^{-2} \mathrm{~s}^{-1}$ in blue-green light), duplicate darks and duplicate time zero controls. Identical samples were incubated over 'white' and 'bluegreen' light, provided by a fan-cooled $500 \mathrm{~W}$ quartzhalogen lamp (GTE Sylvania 500T3Q/CL-120V) with or without a Lee polyester \# 118 blue-green light filter

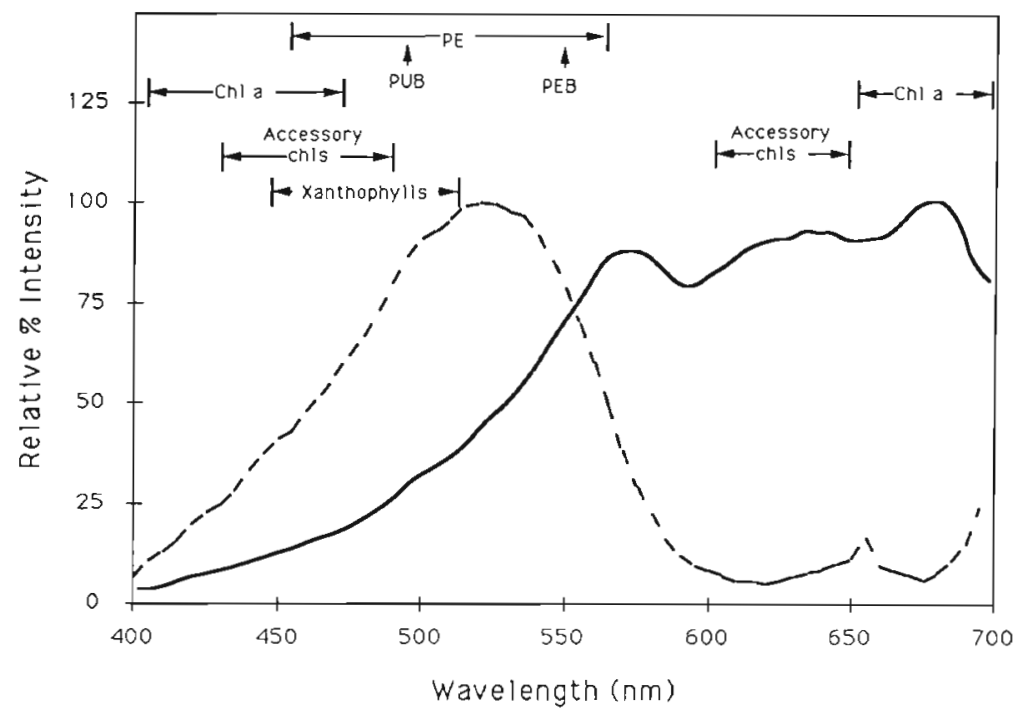

Fig. 1. Spectral output of a tungsten lamp configured in a photosynthetron (see text) in the absence (solid line) and presence (dashed line) of a Lee polyester \#118 blue light filter. The wavelength ranges for light absorption by major pigments present in oceanic phytoplankton are indicated by horizontal bars and include Chlorophyll (Chl) $a$, accessory $C h l b$ and $c$, xanthophylls and phycoerythrin (PE). Absorption peaks for phycourobilin (PUB) and phycoerythrobilin (PEB) chromophores within PE are indicated by arrows 
screen (Fig. 1). The spectral output of the transmitted light was measured at $5 \mathrm{~nm}$ intervals over the visible spectrum, using a Jarrel-Ash model 82-440 Ebert monochromator configured to reduce scattering to $0.0001 \%$. The monochromator was placed $10 \mathrm{~cm}$ from the light source, the path length through the monochromator was $50 \mathrm{~cm}$, and a Li-cor collector was placed at the monochromator exit slit. Emerging light from the monochromator completely covered the irradiance collector, and measurements are reported as percent of maximum spectral output. Data were corrected for the spectral sensitivity of the Li-cor sensor.

Following incubation ( 2 to $3 \mathrm{~h}$ ) in one of 4 white or blue-green light 'photosynthetrons' (Lewis \& Smith 1983) water-cooled to in situ temperature $\left( \pm 2 \mathrm{C}^{\circ}\right)$, both blue-green and white light samples were filtered onto $25 \mathrm{~mm}$ Nuclepore filters of $0.2,0.6,1.0$ and 5.0 $\mu \mathrm{m}$ pore size. Methods of filtration, washing and addition of scintillation cocktail were based on methods described in Prézelin et al. (1986, 1987b). While at sea, isotope incorporation was determined on a portable LKB 1217 scintillation counter which was interfaced with an Apple II microcomputer for data storage and manipulation. Photosynthetic parameters were derived from P-I curves, using procedures detailed in Prézelin et al. (1987b). This approach does not allow an independent assessment of the standard deviation of individual parameters. However, independent determinations of the mean $\mathrm{P}_{\max }$ from averages of data points on the light-saturated portion of the P-I curve, indicated that one standard deviation of $\mathrm{P}_{\max }$ was routinely less than $15 \%$, and often less than $10 \%$, of the mean ( $n=4$ to 10 ). The lower limit of detection for $I_{k}$ (the minimum irradiance required to light-saturate photosynthesis) was $3 \mu \mathrm{E} \mathrm{m} \mathrm{m}^{-2} \mathrm{~s}^{-1}$. Alpha was usually determined as the slope of the light-limited region of the P-I curve. On occasions where $I_{k}$ values were very low $\left(<3 \mu \mathrm{E} \mathrm{m}^{-2} \mathrm{~s}^{-1}\right)$ and insufficient data points were available in the light-limited region of a $\mathrm{P}$ I curve, maximum alpha values were estimated as the quotient $\mathrm{P}_{\max } / \mathrm{I}_{\mathrm{k}}$. Rates of photosynthesis were determined directly for $>0.2,>0.6,>1.0$, and $>5.0 \mu \mathrm{m}$ fraction and by mathematical deduction for the $0.2-0.6,0.6-1.0$ and $1-5 \mu \mathrm{m}$ fractions.

Estimates of water column productivity rates were derived from calculations of in situ photosynthetic performance, $\mathrm{P}_{\mathrm{i}}$, given the relation

$$
\mathrm{P}_{1}=\mathrm{P}_{\max } \tanh \left(\mathrm{I} / \mathrm{I}_{\mathrm{k}}\right)
$$

which requires knowledge of both the diurnal (dawnto-dusk) variations in underwater irradiance (I) and the diurnal patterns in size-fractioned P-I parameters as a function of depth in the water-column (Smith et al. 1987). By combining these estimates of in situ diurnal productivity patterns for each size fraction with mea- surements of midday vertical profiles of in situ $\mathrm{Chl}$ and primary productivity (Prézelin unpubl.), as well as with data on Synechococcus chlorophyll distribution within different size classes as a function of depth and time of day, it was then possible to sum Synechococcus primary production for all size categories and determine the relative contribution that Synechococcus makes to total primary productivity throughout the day at any depth.

\section{RESULTS}

The physical and chemical characteristics of critical depths at the time of sampling in the present study are summarized in Table 1. Details of the temporal variability in water column characteristics during $5 \mathrm{~d}$ at each of the 2 stations are presented elsewhere (Glover et al. 1988a, b). Most notable was the difference in nitrate concentrations in surface waters at the 2 stations. At $\operatorname{Stn} 1$ there was a transient increase in nanomolar ( $\mathrm{n} M$ ) levels of nitrate (to between 21 and $27 \mathrm{nMNO}_{3}$ in the upper $25 \mathrm{~m}$ ) which selectively stimulated a unispecific bloom of Synechococcus spp. (Glover et al. 1988a); at Stn 2 there was neglible temporal variation in phytoplankton biomass and in the surface isothermal layer the nitrate concentrations were less than $10 \mathrm{nM}$ (Glover et al. 1988b).

At both stations, the seasonal thermocline occurred at 25 to $30 \mathrm{~m}\left(24\right.$ to $\left.25^{\circ} \mathrm{C}\right)$ and the depths of the PE maxima, the Chl maxima and the base of the euphotic zones occurred on similar isotherms. PE maxima were located at 80 to $85 \mathrm{~m}$, at 3 to $7 \% \mathrm{I}_{\mathrm{o}}$ and on the $21.5^{\circ} \mathrm{C}$ isotherm. While PE maxima were within the upper region of the nitracline, ammonium was the major form of inorganic nitrogen assayed at these depths (Table 1). Broad Chl maxima occurred 15 to $30 \mathrm{~m}$ below the PE maxima and across the 1 to $3 \%$ isotherm at both stations. The depth of the Chl maximum was shallower at Stn 1, where the downwelling attenuation coefficient $\left(K_{\text {par }}\right)$ was $54 \%$ higher than at Stn 2 (0.056 and 0.037 respectively). Both $\mathrm{Chl}$ maxima were located near the $21^{\circ} \mathrm{C}$ isotherm at nitrate concentrations around 600 $\mathrm{n} M$, although there was twice as much ammonia measured at Stn 1 in comparison to Stn 2. The base of the euphotic zone at the 0.3 to $0.5 \% \mathrm{I}_{\mathrm{o}}$ light depths were at near identical temperatures and were enriched to $\mu \mathrm{M}$ levels of nitrate at both stations. Ammonia levels continued to increase with depth at Stn 1 but decreased at Stn 2, resulting in relative proportions of $\mathrm{NH}_{4}: \mathrm{NO}_{3}: \mathrm{NO}_{2}$ of $1.6: 1.0: 0.07$ and $0.2: 1.0: 0.14$ at the base of the euphotic zone at Stns 1 and 2 respectively.

More than $88 \%$ of the integrated standing crop of Chl $a$ at both stations occurred in the $<5 \mu \mathrm{m}$ fraction (Glover et al. 1988b), indicating ultraphytoplankton dominated the photosynthetic communities. Within the ultraphytoplankton, the depth distribution of PE- 


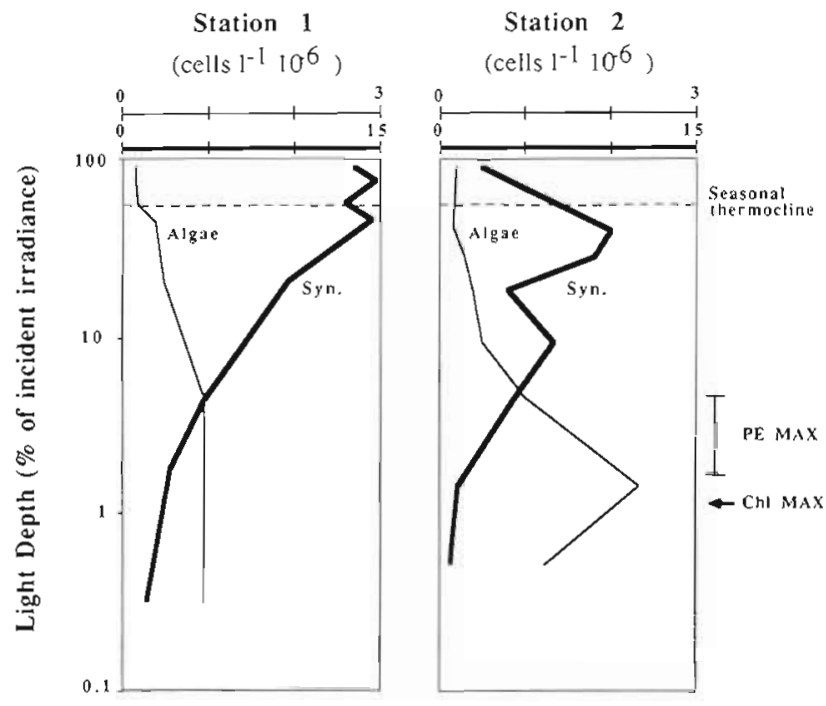

Fig, 2. Profiles of vertical abundances of PE-fluorescing Synechococcus spp. (heavy solid line) and $<5 \mu \mathrm{m}$ Chl-fluorescing algae plotted as a function of light depth at Stns 1 and 2 in the Sargasso Sea. Note the abundance scale for Synechococcus is 5 times greater then that of ultraplankton algae. Depth of seasonal thermocline is indicated by a horizontal dashed line, while depths of PE and Chl maxima are indicated by arrows fluorescing Synechococcus spp. and Chl-fluorescing algae differed distinctly (Fig. 2). At both stations, maximum Synechococcus cell abundance maxima were at light depths $\geq 50 \% \mathrm{I}_{\circ}$, where these cyanobacteria numerically dominated the ultraphytoplankton (note difference in scales used in Fig. 2). Given that Synechococcus cell abundance maxima in surface waters were not coincident with depths of the cyanobacteria-specific PE maxima found deeper in the euphotic zone, it was apparent that the deeper populations of Synechococcus were comparatively dilute in number but were enriched in cellular light-harvesting phycoerythrin (for greater detail, see Glover et al. 1988b). Conversely, abundances of Chl-fluorescing ultraplankton were low in surface waters but increased within the nitracline where both the PE and Chl maxima occurred. Near and below the $2 \% I_{0}$ depth, abundances of ultraplankton algae and Synechococcus cells are approximately equal within the same community.

A comparison of blue-green versus white light effects was made for Chl-specific rates of photosynthesis in whole water communities $(>0.2 \mu \mathrm{m})$ under light-saturating $\left(\mathrm{P}_{\mathrm{max}}\right)$ and light-limiting (alpha) conditions. The values of these parameters as well as the related variable $I_{k}\left(P_{\text {max }}:\right.$ alpha $)$ are displayed in Fig. 3 to 5. Diurnal

Station 1

Station 2

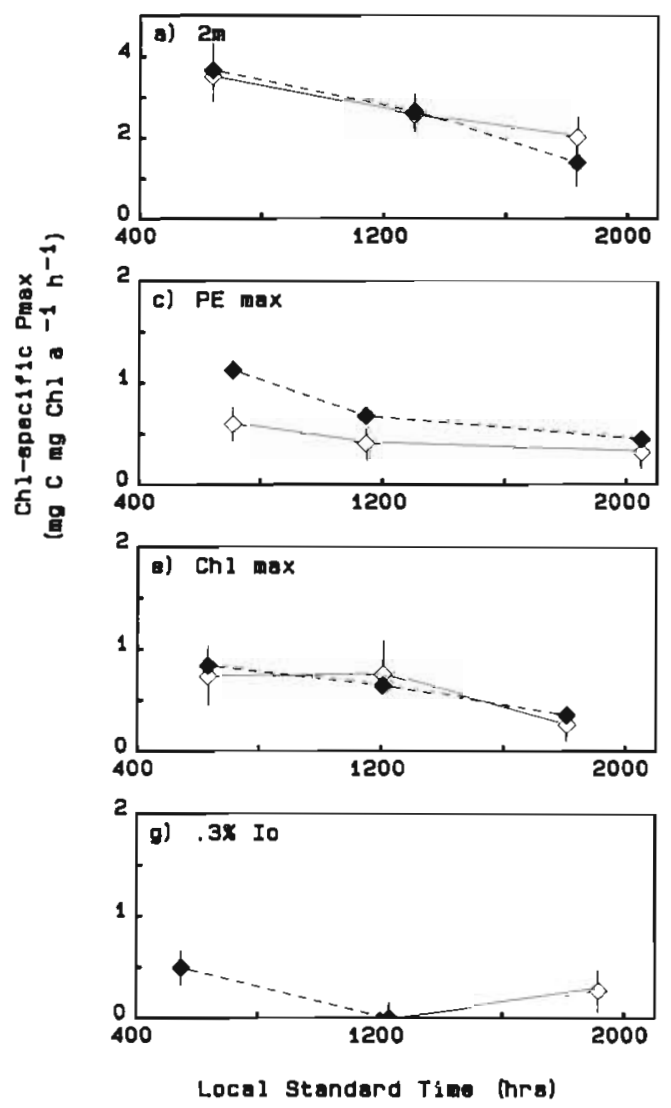

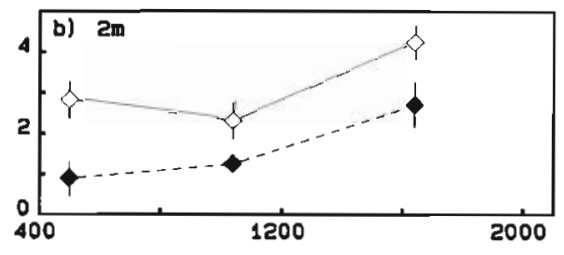
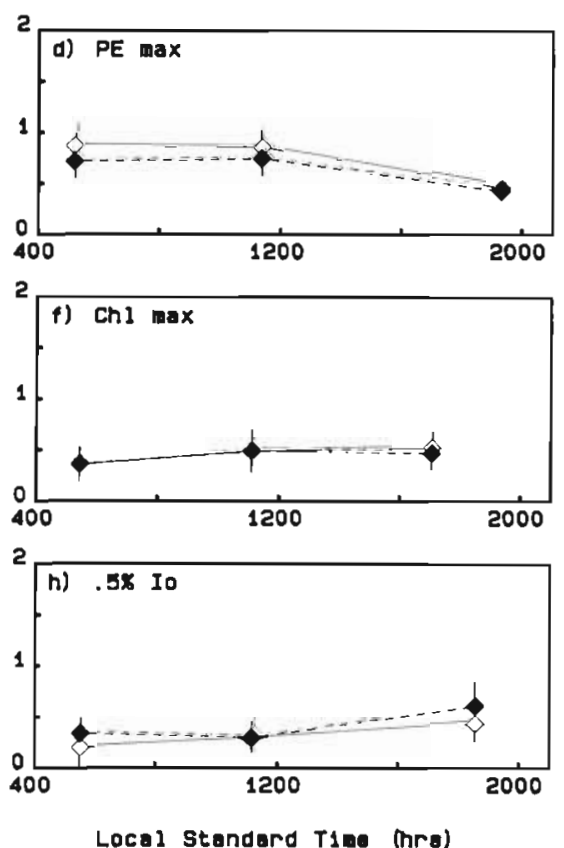

Fig. 3. Comparison of bluegreen $(\bullet)$ and white $(\diamond)$ tungsten light measurements of Chl-specific rates of light-saturated photosynthesis $\left(\mathrm{P}_{\max }\right)$ of whole water phytoplankton communities $(>0.2 \mu \mathrm{m})$ sampled over the day from $(a$, b) the surface $(2 \mathrm{~m}) ;(\mathrm{c}, \mathrm{d})$ the PE $\max _{;}(e, f)$ the Chl $\max$; and $(g, h)$ the base of the euphotic zone $<0.5 \%$ $\mathrm{I}_{\mathrm{o}}$ ) at 2 stations in the Sargasso Sea. Vertical bars indicate 1 standard deviation of the mean 
Station 1

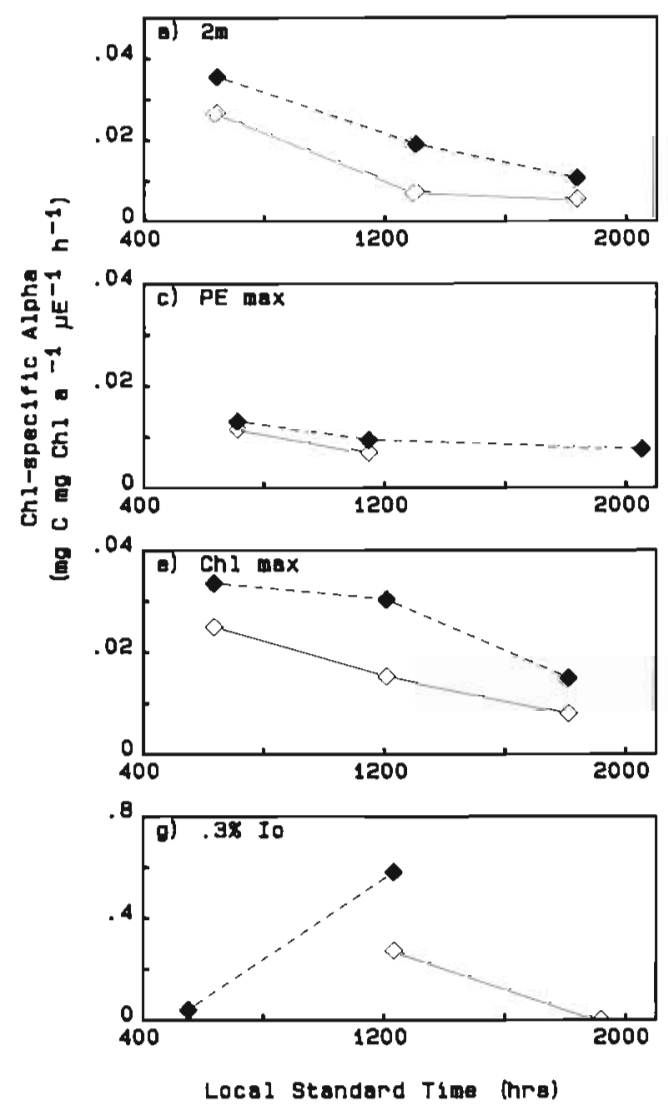

Station 2
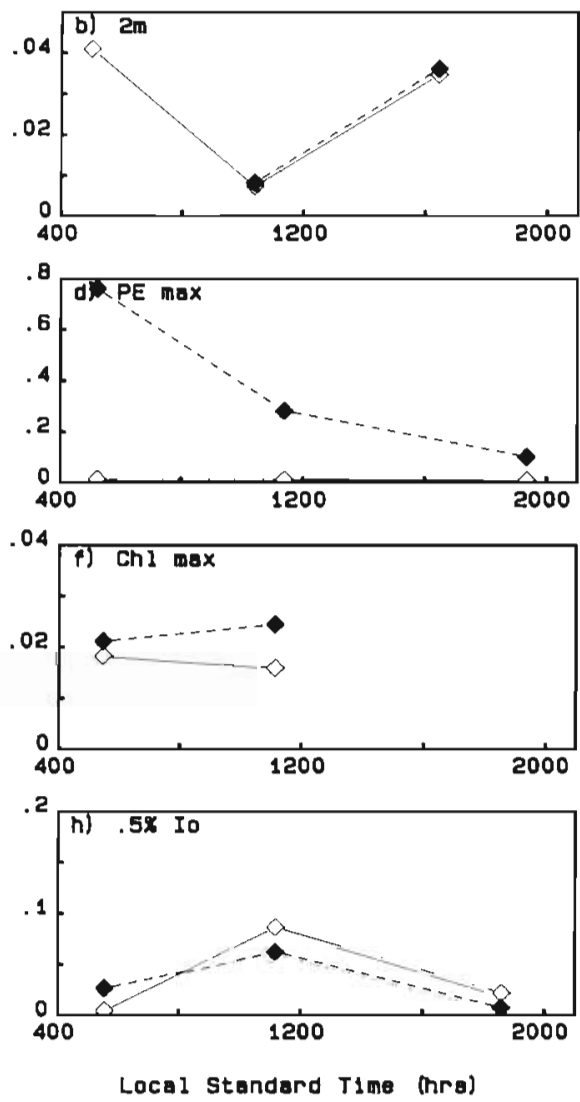

Fig. 4. Comparison of blue-green $(\downarrow)$ and white $(\diamond)$ tungsten light measures of Chl-specific rates of light-limited photosynthesis (alpha) of whole water phytoplankton communities $(>0.2 \mu \mathrm{m})$ sampled over the day from $(a, b)$ the surface $(2 \mathrm{~m}) ;\left(c_{1}\right.$ d) the phycoerythrin maximum (PE max); ( $\mathrm{e}, \mathrm{f})$ the Chlorophyll maximum (Chl max); and ( $\mathrm{g}, \mathrm{h}$ ) the base of the euphotic zone (<0.5\% $\left.\mathrm{I}_{0}\right)$ at 2 stations in the Sargasso Sea. Only alphas with regressed linearities $>0.65(n>4)$ were plotted, although most alphas plotted had $r$ values $>0.85$ and $n=7$ to 13

patterns of daytime changes in $\mathrm{P}_{\max }$ and alpha were generally the same when measured under blue-green or white light incubation conditions (an exception being the alpha values for PE max at Stn 2, Fig. 4d). Midday maxima in photosynthetic rates were not routinely observed, the highest rates of light-saturated and light-limited photosynthesis being measured during early morning hours. The magnitude of daytime changes in Chl-specific $P_{\max }$ damped with depth, being greatest in surface waters (about 3-fold) where assimilation rates were also highest (Fig. 3). The magnitude of daytime changes in Chlspecific alpha were as high as 8 -fold but did not show a depth-dependent relationship (Fig. 4). Highest alpha values were observed at the base of the euphotic zone and within the PE max at Stn 2 . Since changes in $P_{\max }$ and alpha did not covary, diurnal patterns in $I_{k}$ were evident and were distinctly different at individual depths at the 2 stations (Fig. 5). With the exception of the base of the euphotic zone, highest $I_{k}$ values at all other sampling depths were observed at midday and were up to 7 -fold higher than either dawn or dusk measurements. Diurnal variations in $I_{k}$ dampened with depth and mean daily $I_{k}$ values declined with depth.

For most samples, blue-green and white light incubation conditions did not influence the measured rates of Chl-specific $P_{\text {max }}$. One exception was evident during morning within the PE max at Stn 1 (Fig. 3c), when bluegreen light measurements of $\mathrm{P}_{\max }\left(\mathrm{P}_{\max }\right.$ blue) were twice at great as white light measurements of $P_{\max }\left(P_{\max }\right.$ white). Conversely, a second exception was detected in surface waters at Stn 2 where the value of $P_{\max }$ blue measured throughout the day were only about half of those measured for $P_{\max }$ white (Fig. 3b). Blue-green light measurements of alpha (alphablue) were routinely equal or higher

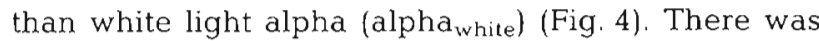
one exception at the base of the euphotic zone, where estimates of alpha were particularly difficult to make owing to the very low biological activity of the samples. The magnitude of alphablue:alpha white $_{\text {varied with time }}$ of day and was greated at Stn 2 in PE max populations 
Station 1
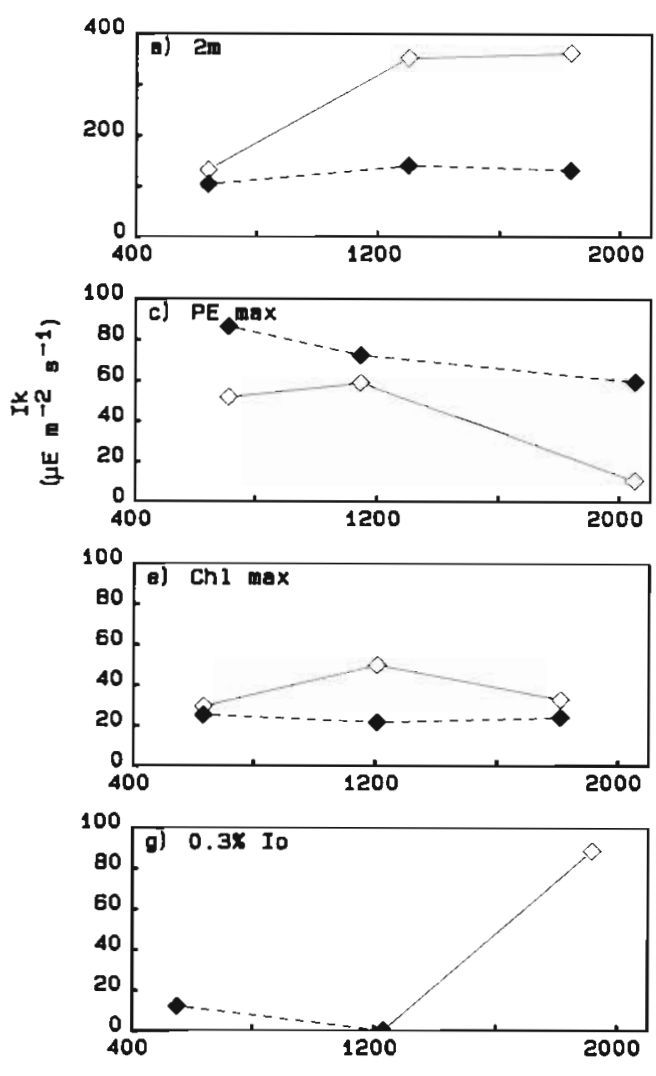

Local Standard Tieg (hre)
Station 2
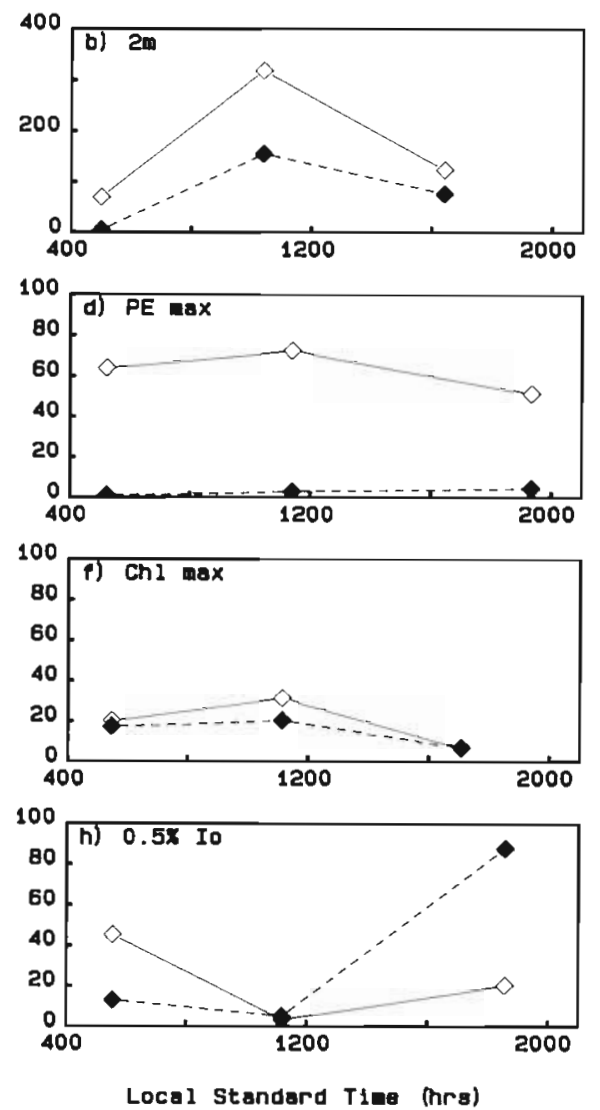

Fig. 5. Comparison of blue-green $(\bullet)$ and white $(\diamond)$ tungsten light measures of $I_{k}\left(=P_{\max }\right.$ : alpha) for whole water phytoplankton communities $(>0.2 \mu \mathrm{m})$ sampled over the day from $(\mathrm{a}, \mathrm{b})$ the surface $(2 \mathrm{~m}) ;(\mathrm{c}, \mathrm{d})$ the PE max; $(\mathrm{e}, \mathrm{f})$ the $C h \mathrm{max}$; and $(\mathrm{g}$, $h)$ the base of the euphotic zone $\left(<0.5 \% \mathrm{I}_{0}\right)$ at 2 stations in the Sargasso Sea

dominated by PE-enriched Synechococcus populations (Fig. 3). The resultant combined effect of blue-green lightincubation conditions on estimates of both $\mathrm{P}_{\max }$ and alpha was that whole water samples required much lower irradiances of blue-green light than white light to saturate in situ rates of community photosynthesis. These observations are evident in the much lower $I_{k}$ values measured under blue-green light ( $\mathrm{I}_{\mathrm{k}}$ blue) than white light ( $\mathrm{I}_{\mathrm{k}}$ white) for all samples except the PE max at Stn 1 (Fig. 5).

In situ photosynthetic performance $\left(\mathrm{P}_{\mathrm{i}}\right)$ was estimated from combined knowledge of P-I parameters and the underwater light field. A comparison of $P_{i}$ estimates derived from white light P-I parameters and blue-green light P-I parameters for whole water $(>0.2$ um) communities and the $0.6-1 \mu \mathrm{m}$ size fraction is given in Table 2 . Note that in some instances the differences between blue-green and white light estimates were independent of time of day, while in other instances blue-green vs white light $P_{i}$ estimates were much greater at one time of day than another. For samples taken from below surface waters, blue-green light incubations generally gave rise to higher estimates of in situ productivity. The difference between white and blue-green light estimates of $P_{1}$ showed an increasing trend with depth for whole water communities. In surface waters, blue-green light estimates were similar to or were significantly less than white light estimates of photosynthetic performance. Interestingly, the magnitude of the blue-green vs white light increases were similar for whole water communities sampled at similar light depths at the 2 stations. For the 0.6-1 um size fraction, blue-green light incubation led to 3 -fold higher estimates of photosynthetic performance at Stn 1 and 3-fold lower estimates of photosynthetic performance at Stn 2 . Within the PE max at both stations, blue-green light estimates were about $40 \%$ higher than white light estimates. Within the Chl max at both stations, bluegreen light estimates for the $0.6-1 \mu \mathrm{m}$ fraction were 2 to 3-fold higher than white light estimates.

To further define the differential effect blue-green light incubations might have on Synechococcus and algal subpopulations of ultraphytoplankton within the 
Table 2. Blue-green:white ratio of estimates of in situ rates of photosynthetic performance $\left(P_{1}\right)$ in subsurface whole water $(>0.2 \mu \mathrm{m})$ and $0.6-1.0 \mu \mathrm{m}$ size-fractioned communities from 2 stations in the Sargasso Sea in July-August 1986. Samples were collected at different times of the day and replicates incubated under equal fluences of bluegreen or white light. Estimates of $P_{1}$ were derived from knowledge of $P_{-}$I parameters and the underwater light field. PE max and Chl max as in Table 1

\begin{tabular}{|c|c|c|c|c|}
\hline \multirow[t]{2}{*}{ Sample depth } & \multicolumn{4}{|c|}{ Blue-green $P_{1}$ : White $P_{i}$} \\
\hline & Dawn & Noon & Dusk & $\bar{X} \pm S D$ \\
\hline \multicolumn{5}{|l|}{$>0.2 \mu \mathrm{m}$} \\
\hline \multicolumn{5}{|l|}{ Surface $(2 \mathrm{~m})$} \\
\hline Stn 1 & 1.04 & 1.03 & 0.72 & $0.93 \pm 0.18$ \\
\hline Stn 2 & 0.32 & 0.54 & 0.64 & $0.50 \pm 0.14$ \\
\hline \multicolumn{5}{|l|}{ PE max } \\
\hline Stn 1 & 0.67 & 1.37 & 0.70 & $0.91 \pm 0.40$ \\
\hline Stn 2 & 2.75 & 0.87 & 1.90 & $1.89 \pm 0.94$ \\
\hline \multicolumn{5}{|l|}{ Chl max } \\
\hline Stn 1 & 1.35 & 1.98 & 1.88 & $1.73 \pm 0.33$ \\
\hline Stn 2 & 1.76 & 0.99 & 0.89 & $1.21 \pm 0.47$ \\
\hline \multicolumn{5}{|l|}{$\begin{array}{l}\text { Base of } \\
\text { euphotic zone }\end{array}$} \\
\hline Stn 1 & 1.00 & 3.88 & 2.98 & $2.62 \pm 1.47$ \\
\hline $\operatorname{Stn} 2$ & 5.90 & 1.03 & 0.32 & $2.42 \pm 3.03$ \\
\hline \multicolumn{5}{|l|}{$0.6-1.0 \mu \mathrm{m}$} \\
\hline \multicolumn{5}{|l|}{ Surface (2 m) } \\
\hline Stn 1 & - & 4.95 & 1.11 & $3.03 \pm 2.72$ \\
\hline $\operatorname{Stn} 2$ & 0.33 & 0.34 & - & $0.34 \pm 0.01$ \\
\hline \multicolumn{5}{|l|}{ PE max } \\
\hline Stn 1 & 2.44 & 0.93 & 0.80 & $1.39 \pm 0.91$ \\
\hline $\operatorname{Stn} 2$ & 1.96 & 0.79 & 1.45 & $1.40 \pm 0.59$ \\
\hline \multicolumn{5}{|l|}{ Chl max } \\
\hline Stn 1 & 1.02 & 3.18 & 2.94 & $2.38 \pm 1.18$ \\
\hline Stn 2 & - & 3.55 & 2.68 & $3.12=0.62$ \\
\hline \multicolumn{5}{|l|}{$\begin{array}{l}\text { Base of } \\
\text { euphotic zone }\end{array}$} \\
\hline Stn 1 & $>6.00$ & - & - & - \\
\hline Stn 2 & - & - & - & - \\
\hline -: Insufficient & a to $\mathrm{cor}$ & te c & ations & \\
\hline
\end{tabular}

size-fractioned communities at both stations, the distribution of $\mathrm{Chl}$ biomass between the 2 components was first calculated within different size fractions between 0.2 and $5 \mu \mathrm{m}$ in size. Fig. 6 displays the percentage of total Chl biomass attributable only to Synechococcus spp. within different size fractions sampled at similar light depths at both stations. Synechococcus Chl biomass accounted for virtually all ultraphytoplankton Chl in $<5 \mu \mathrm{m}$ size fractions sampled from surface waters and more than $80 \%$ of Chl biomass in $<1 \mu \mathrm{m}$ size fractions sampled from the PE max at both stations. Contribution to the 1-5 $\mu \mathrm{m}$ fraction with the PE max was dominated by algae at Stn 1 and by Synechococcus at Stn 2 . Below the PE max at Stn 1, Synechococcus biomass accounted

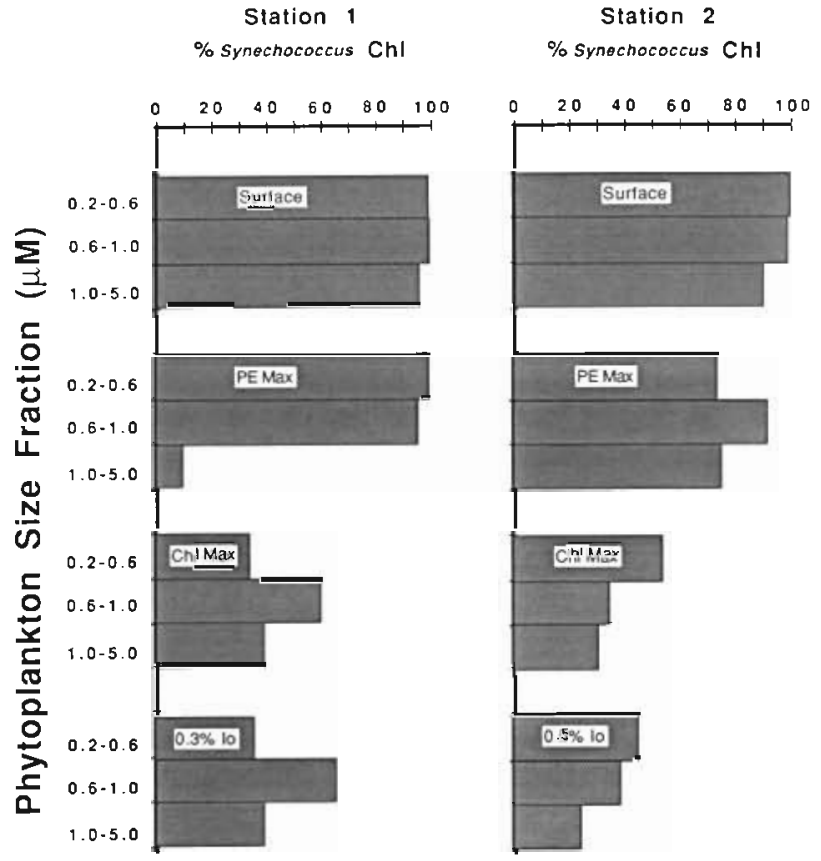

Fig. 6. Comparison of percentage of total $\mathrm{Chl}$ biomass attributable to Synechococcus spp. within different size fractions sampled at the surface, within the PE max and Chl max, and the base of the euphotic zone $\left(<0.5 \% \mathrm{I}_{\mathrm{o}}\right)$ at 2 stations in the Sargasso Sea

for the majority of Chl within the 0.6-1 $\mu \mathrm{m}$ size fraction only, with eukaryotic algae accounting for the majority of Chl biomass in the $0.2-0.6$ and $1.5 \mu \mathrm{m}$ fractions at the Chl max and the base of the euphotic zone. At Stn 2, the Chl distribution below the PE max was dominated by algae in all size fractions with the Synechocuccus contribution declining with increasing size fraction in communities sampled from the Chl max and the base of the euphotic zone.

Fig. 7 and 8 display the ratios of blue-green vs white estimates of Chl-specific $P_{\max }$ and alpha within different phytoplankton size fractions as a function of depth at the 2 stations. Surface values were sorted by time of day, while values for other depths represent the means of daily averages. For $\operatorname{Stn} 1$, whole community $(>0.2 \mu \mathrm{m})$ measures of $P_{\max }$ blue: $P_{\max }$ white approximated $1: 1$ and most subfractions within the same sample reflected whole community values. Notable exceptions were at midday within surface $0.6-1$ and $1-5 \mu \mathrm{m}$ fractions, exclusively comprised of Synechococcus Chl biomass, where blue-green light measures of $P_{\max }$ were $\geq 4$ times greater than white light measures of $P_{\max }$. Similar bluegreen light enrichment of $\mathrm{P}_{\max }$ values was observed at various times of day for Synechococcus-dominated population within the PE max, but were less evident in size fractions where mixed populations of cyanobacteria and eukaryotic algae were found. At Stn 2, whole communities sampled from surface waters over the day 
and incubated under blue-green light actually showed only half the photosynthetic potential of white light samples. With increasing depth, whole water values for $P_{\max }$ blue: $P_{\max }$ white steadily increased toward a value of 1.5 at the base of the euphotic zone. Size fractions within whole water communities showed similar $P_{\max }$ blue:Pmaxwhite values, with the one exception of the $0.6-1 \mu \mathrm{m}$ mixed community of the $\mathrm{Chl}$ maximum

Blue-green light enrichment of measured rates of light-limited photosynthesis was common at all depths at both stations, with greatest alpha blue $_{\text {alpha }}$ white ratios associated with size fractions in which Synechococcus Chl biomass dominated phytoplankton samples (Figs. 6 and 8). Greater than 5-fold increases in Chl-specific alpha were evident when alphablue:alpha white ratios were compared for surface $0.2-0.6$ and $0.6-1 \mu \mathrm{m}$ fractions at Stn 1 (95\% Synechococcus Chl) and 0.2-0.6 $\mu \mathrm{m}$ fraction at Stn 2 (72\% Synechococcus Chl); and Chl $\max$ 0.6-1 um fraction at Stn 1 (60\% Synechococcus Chl). Working with only surface and PE max 0.6-1 $\mu \mathrm{m}$ size fractions, in which Synechococcus spp. accounted for $\geq 95 \%$ of Chl biomass (Fig. 6), it was evident that ChI-specific blue-green light alpha values increased in direct proportion $(r=0.94)$ to the PE concentration within these cyanobacteria (Fig. 9).

Photosynthetic parameters derived from white light measurements of P-I relations were used to estimate in situ rates of photosynthetic performance $\left(\mathrm{P}_{\mathrm{i}}\right)$ for whole water $(>0.2 \mu \mathrm{m})$ communities and Synechococcus subcomponents and these were compared to estimates based upon blue-green light incubations. At Stn 1, the impact of blue-green light incubations was to increase total water column production estimates by less than $6 \%$ (from 360 to $380 \mathrm{mg} \mathrm{Cm}^{-2} \mathrm{~d}^{-1}$ ) but to increase estimates of Synechococcuscontribution to that production from 57 to $73 \%$ (Fig. 10). Similarly at Stn 2, the use of blue-green light incubation had much less effect on estimates of whole community production (which increased 13\% under blue-green light conditions) than on estimates of Synechococcus spp. contribution to water column productivity (Fig. 11). Due primarily to increases in alpha estimates under blue-green light conditions for PE max populations of Synechococcus, estimates of Synechococcus spp. contribution to total water column productivity rose from $61 \%$ under white light conditions to $84 \%$ under blue-green light conditions at Stn 2 (Fig. 11).

\section{DISCUSSION}

The determination of photosynthesis-irradiance (P-I) parameters in phytoplankton communities is important because they can be used to discern temporal/spatial patterns of in situ productivity, quantum yield, photosynthetic potential and/or susceptibility to photoinhibi-

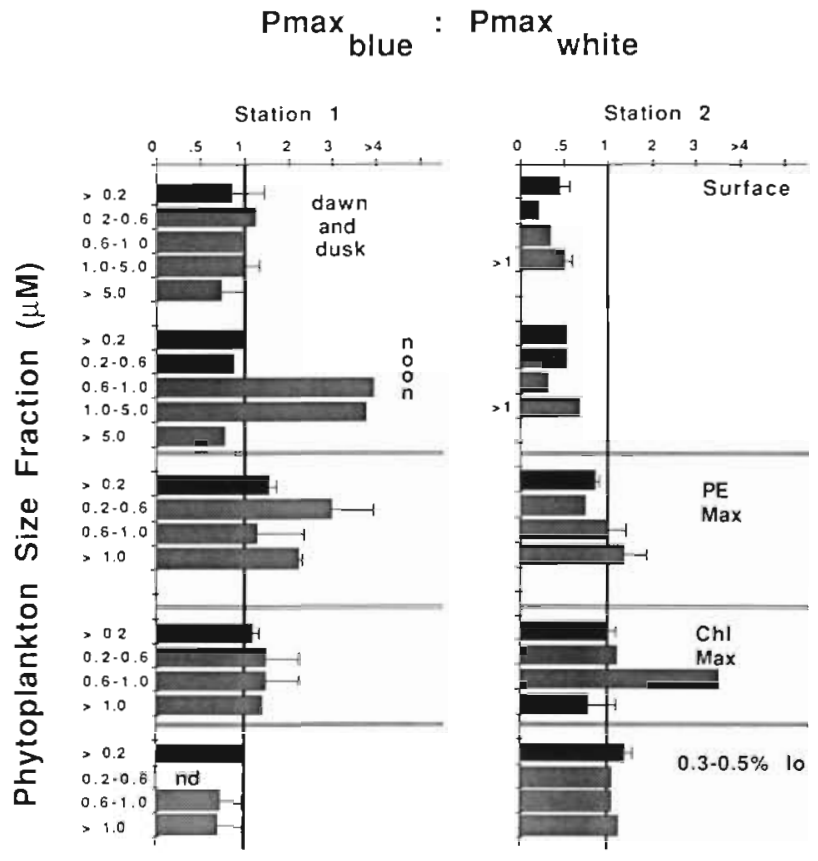

Fig. 7. Comparison of ratio of blue-green vs white tungsten light measures of $\mathrm{P}_{\max }$ in different size fractions of phytoplankton sampled over the day from the surface $(2 \mathrm{~m}), \mathrm{PE}$ max, Chl max and the base of the euphotic zone $\left(<0.5 \% I_{0}\right)$ at 2 stations in the Sargasso Sea. Ratios of $P_{\max }$ blue: $P_{\max }$ white for whole water communities $(>0.2 \mu \mathrm{m})$ are shown as black bars; ratios for size-fractioned $(0.2-0.6,0.6-1,1-5,>1,>5 \mu \mathrm{m})$ communities are shown as hatched bars. In surface samples, noontime data was sorted out and compared to the mean of replicate measurements made at dawn and/or dusk. At PE max, Chl max and base of euphotic zone, the mean of all daytime measurements ( $n=1$ to 3 ) of blue-green: white $P_{\max }$ ratio is presented. Vertical bars indicate 1 standard deviation of means

tion, from which bio-optical models of oceanic productivity can be tested (Bidigare et al. 1987, Prézelin et al. 1987a, Smith et al. unpubl.). In order to measure P-I relationships of phytoplankton up to light levels equal to midday sun at the ocean surface, shipboard incubators are routinely used with short-term exposure to a range of irradiances generated by high intensity tungsten lamps. However, the spectral output from this 'white' light source is known to be enriched in red wavebands that favor light absorption by Chl a found in all photosynthetic cells and by accessory Chls ( $\mathrm{Chl} b$ and $\mathrm{Chl} c$ ) found in chlorophytes, prochlorophytes and chromophytic algae (Fig. 1) (Prézelin \& Boczar 1986). While such spectral biasing of incubation illumination might be expected to lead to errors in productivity estimates (Kiefer \& Strickland 1970), the actual use of white light P-I parameters to predict independently derived estimates of in situ productivity patterns for mixed diatom and prymnesiophyte communities has recently proved quite satisfactory (Prézelin et al. $1987 \mathrm{a}$, Smith et al. unpubl.). These coastal communities have several 


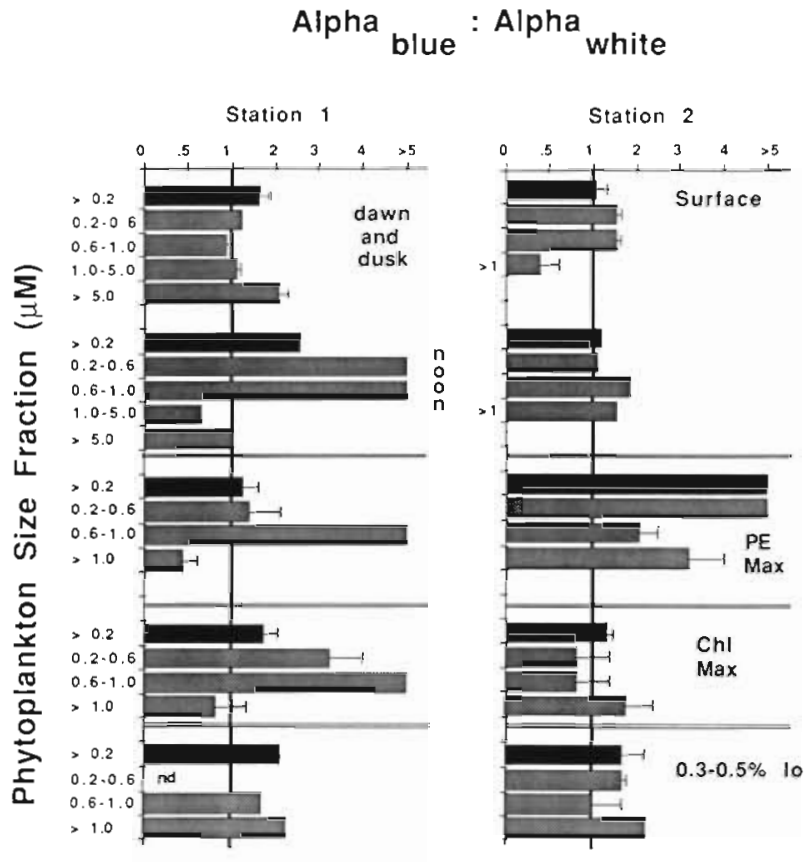

Fig. 8. Comparison of ratio of blue-green vs white tungsten light measures of chl-specific alpha in different size fractions of phytoplankton sampled over the day from the surface $(2 \mathrm{~m})$, $\mathrm{PE} \max , \mathrm{Chl} \max$ and the base of the euphotic zone $<0.5 \%$ $\left.I_{0}\right)$ at 2 stations in the Sargasso Sea. Ratios of alphablue $_{\text {alpha white }}$ for whole water communities $(>0.2 \mu \mathrm{m})$ are shown as black bars; ratios for size-fractioned $(0.2-0.6$, $0.6-1,1-5,>1,>5 \mu \mathrm{m})$ communities are shown as hatched bars. In surface samples, noontime data was sorted out and compared to the mean of replicate measurements made at dawn and/or dusk. At PE max, Chl max and base of euphotic zone, the mean of all daytime measurements $(n=1$ to 3$)$ of blue: white alpha ratio is presented. Vertical bars indicate 1 standard deviation of mean values

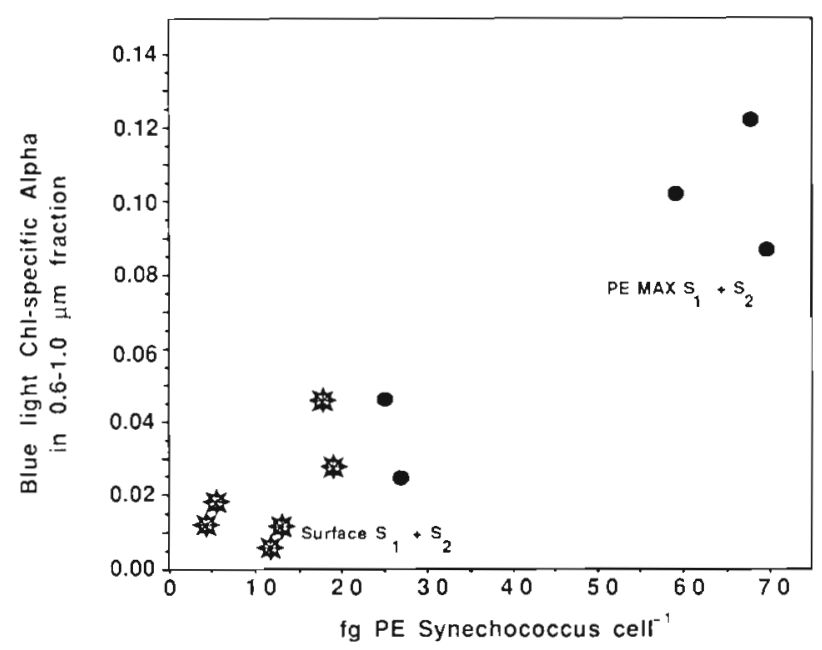

Fig. 9. Variations in blue-green light measures of Chl-specific alpha as a function of variations in cellular PE concentrations in Synechococcus populations sampled from the surface (stars) and within the PE max (circles) at 2 stations in the Sargasso Sea. The correlation coefficient for the linear regression of the data was 0.94 features that may reduce their susceptibility to spectral bias by the tungsten incubation lamp source. First, the high abundance and species diversity within coastal assemblages may result in a spectral averaging of light absorption by the whole community that overcomes the spectral bias of the light field. Second, photosynthetic absorption and action spectra suggest that red and blueviolet light are functionally equivalent in light-harvesting capabilities by the accessory Chls that drive much of the photosynthetic activity of chromophytic and $\mathrm{Chl} b$ containing organisms that dominate coastal waters (Prézelin \& Boczar 1986). Lastly, there is less spectral dependency in the distribution of absorbed photosynthetic excitation energy between photosystems I and II in Chl $c$ - and Chl b-containing algae than in the phycobilinrich systems of cyanobacteria (Prézelin \& Boczar 1986), which represent only a small fraction of the phytoplankton biomass in coastal regions.

The present study was prompted by questioning whether the spectral bias of 'white' light might be inappropriate for estimating oceanic primary productivity and in defining the photophysiological characteristics of cyanobacterial populations of PE-rich Synechcococcus spp. One reason for concern arose from the knowledge that these cyanobacteria routinely dominate phytoplankton species abundance above the Chl max in the open ocean (Glover et al. 1988a, b) and blue-green light absorbed by PE alone can account for a large majority of the photosynthetically fixed carbon in the cell (Lewis et al. 1987, Boucher et al. unpubl.). The use of conventional tungsten 'white' light sources in photosynthetrons would therefore minimize the light-harvesting capabilities of $\mathrm{PE}$ and lower its contribution to photosynthetic carbon fixation. Some of the spectral bias in 'white' light sources can be overcome by placing colored filters over the tungsten lamps, such that the spectral output of the incubation illumination both simulates the spectral quality of light fields within the upper water-column of the open sea (Jerlov 1976) and overlaps the broad 485 to $565 \mathrm{~nm}$ maximum in spectral quantum yield for PE-driven photosynthesis that is characteristic of PE-rich cyanobacteria (Lewis et al. 1986, Boucher et al. unpubl.). The aim of the present study was to assess the impact of blue-green versus 'white' light incubation on primary productivity estimates of Sargasso Sea communities dominated by Synechococcus and to determine if any observed differences could be linked to other photophysiological characteristics of these cyanobacterial populations.

\section{Blue-green versus 'white' light effects on P-I parameters}

Diurnal (daytime) periodicity of $P_{\max }$ and alpha have been documented for ultraphytoplankton communities 


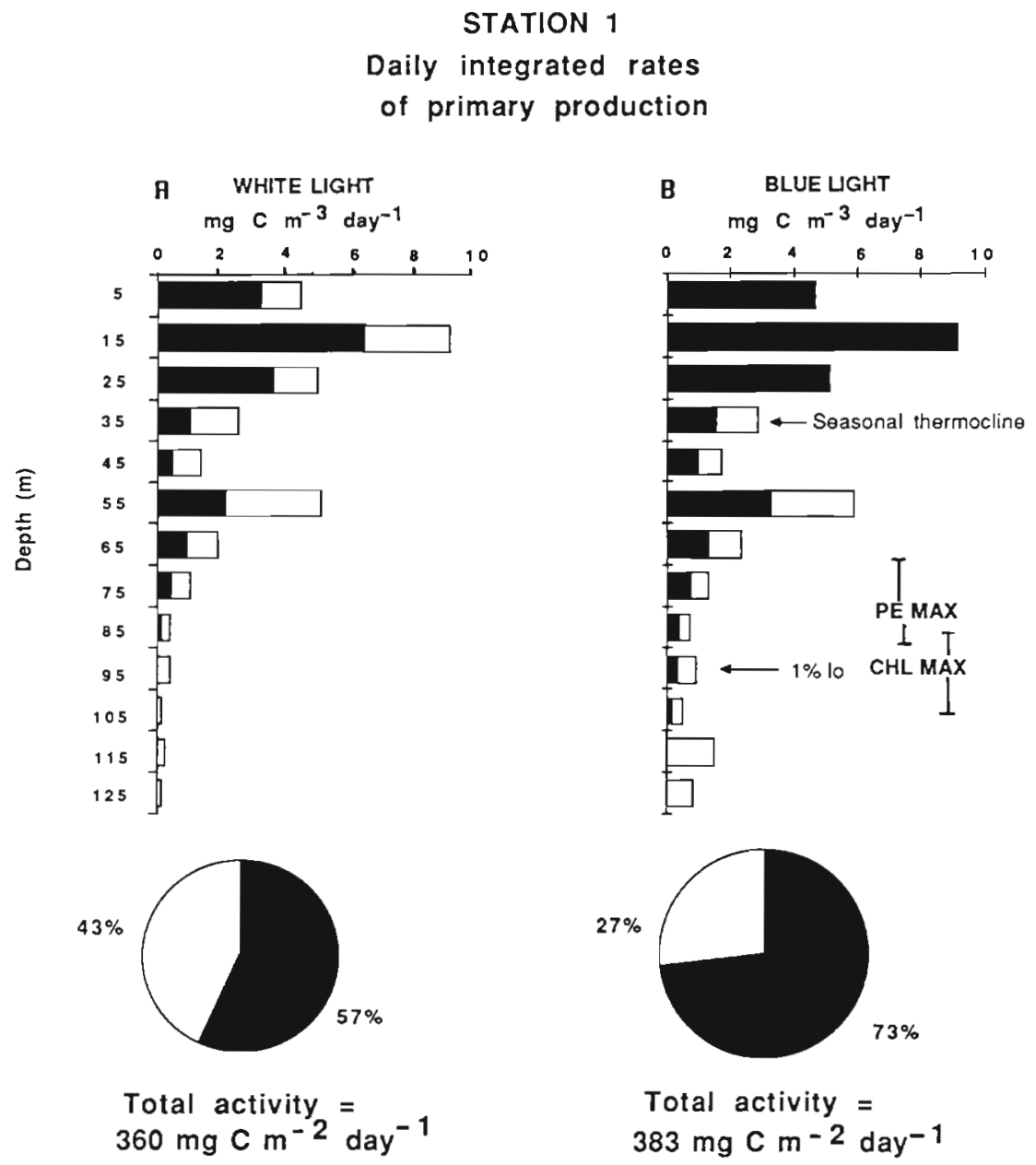

Fig. 10. Depth profiles of daily integrated rates of in situ primary production at Stn 1 in the Sargasso Sea, comparing estimates derived from (A) white light measures and (B) blue-green light measures of diurnal carbon fixation. Summation of water-column daily integrated rates of production are shown as a pie-diagram beneath each depth profile. Fractional contribution by Synechococcus spp. subpopulations to whole communities production ( $>0.2 \mu \mathrm{m}$, length of bars) is shown by the black bars on the depth profile and the black portion of the pie-diagrams

dominated by PE-rich Synechococcus (Putt \& Prézelin 1985, Prézelin et al. 1986, 1987b, c). These studies demonstrated depth-dependent and water massdependent changes in the timing and amplitude of daytime variations in photosynthesis, which were independent of Chl concentrations and dark rates of carbon fixation. Generally, the timing of peak photosynthetic potential occurred between dawn and midday and were or were not coincident with diurnal variations in alpha. The amplitude of diurnal variations in $\mathrm{P}_{\max }$ and alpha tended to dampen with depth. Laboratory experiments have shown that diel periodicity in Synechococcus photosynthesis is not driven by a biological clock (Sweeney \& Borgese 1988), but is linked to changes in cell cycle photobiology (Boucher et al. unpubl.). In the present study, diumal patterns of $\mathrm{P}_{\max }$ and alpha in whole water samples at both stations were characterized by low amplitudes and when evident at all, peak activities occurred at times other than midday. While the possible mechanisms to account for wavelength-dependence of $P_{\max }$ and alpha are described below, it can be concluded that time of day can influence the degree of spectral dependency evident in the photosynthetic activity of an oceanic phytoplankton community.

The present study generally demonstrated $P_{\max }$ to be a wavelength-independent parameter for oceanic ultraphytoplankton $(<5 \mu \mathrm{m})$ communities (Fig. 7). However, there were 2 clear exceptions, both involving surface ultraphytoplankton that were almost exclusively comprised of Synechococcus cells. First, at Stn 1 there were 2 surface subpopulations of Synechococcus in 0.6-l and 1-5 $\mathrm{mm}$ fractions, which showed a greater than 4-fold increase in $P_{\max }$ when incubated under blue-green instead of white light at midday (Fig. 7). Concurrent measurements determined that there was 


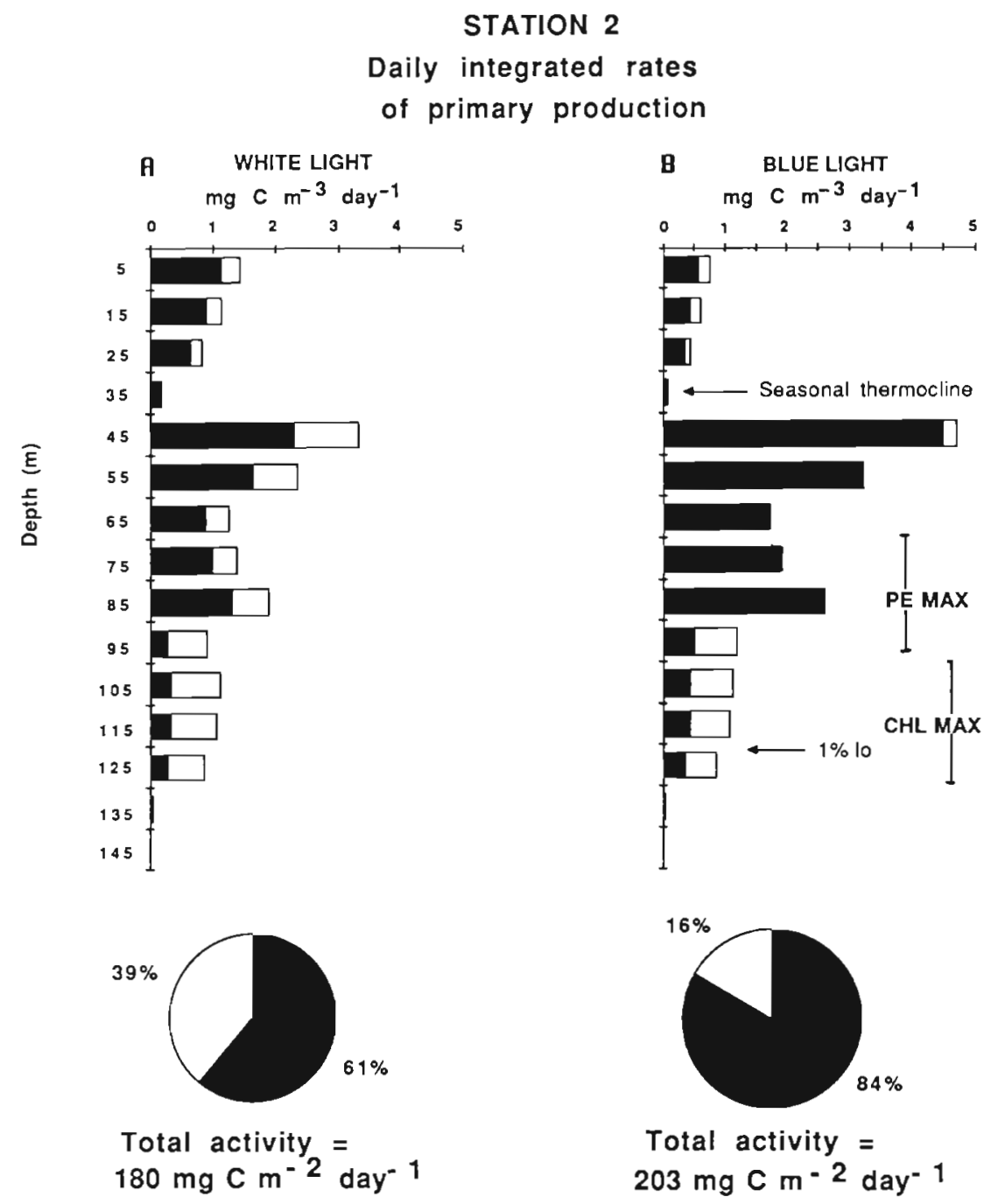

Fig. 11. Depth profiles of daily integrated rates of in situ primary production at Stn 2 in the Sargasso Sea, comparing estimates derived from (A) white light measures and (B) blue-green light measures of diurnal carbon fixation. Summation of water-column daily integrated rates of production are shown as a pie-diagram beneath each depth profile. Fractional contribution by Synechococcus spp. subpopulations to whole communities production ( $>0.2 \mu \mathrm{m}$, length of bars) is shown by the black bars on the depth profile and the black portion of the pie-diagrams

no discernable change in the $\mathrm{PE} / \mathrm{Chl}$ ratio within these size fractions at this time (unpubl.). This $P_{\max }$ blue-green $: P_{\max }$ whte increase was not evident at all in independent whole water estimates, which combined ultraphytoplankton communities with the $>5 \mu \mathrm{m}$ fraction (Fig. 3). One explanation for the blue-green light increases in Synechococcus $\mathrm{P}_{\max }$ might be a midday 'white' light-driven photoinhibition, whereby the unrealistic biasing in incubation illumination away from blue-green to red wave bands could have altered the cellular balance between the various deexcitation mechanisms which normally protect the photosynthetic components from photoinhibitory effects (cf. Powles 1984).

The second example of spectral effects on estimates of $P_{\max }$ occurred in surface waters at $\operatorname{Stn} 2$, where throughout the day all size fractions of ultraphytoplankton communities consistently gave blue-green light $P_{\text {max }}$ estimates that were only half of those measured under 'white' light (Fig. 7). Like Stn 1, Synechococcus populations accounted for $\geq 90 \%$ of all ultraphytoplankton Chl in surface waters (Fig. 6). It is not clear whether these results indicate a blue-green light induced decrease or 'white' light induced increase in $\mathrm{P}_{\text {max }}$, but it was apparent that the difference occurred independently of cyanobacterial size or time of day. One possible explanation is that nitrogen limitation in the Stn 2 Synechococcus population could be linked to a general mobilization of PE protein reserves to such an extent that the light-harvesting phycobilins were effectively decoupled from photosynthesis. Nitrate concentrations in surface waters at Stn 2 were less than half of 
those measured at Stn 1, where a recent input appeared to have induced a Synechococcus bloom that was characterized by cells with a high PE content (Glover et al. 1988a, b). In contrast, surface Synechococcus cells at Stn 2 had only half the PE content as those at Stn 1, but contained the same amount of Chl. These observations are consistent with laboratory studies, which have shown nutrient deficient cyanobacterial cells contain normal Chl levels, while phycobilins are degraded and has led to the conclusion that light-harvesting phycobilins such as PE can also function as a nitrogen reserve (Boubissa \& Richmond 1980 , Wyman et al. 1985, Carr \& Wyman 1986). Furthermore, the spectral quantum yield for photosynthesis, which is driven by $\mathrm{PE}$ light absorption, is markedly reduced in nutrient-depleted Synechococcus cells, while that of ChI remains about the same (Lewis et al. 1986, Boucher et al. unpubl.). If nutrient stress resulted in a decoupling of $\mathrm{PE}$ from the Chl-containing phototraps of Synechococcus, then photosynthesis could have been driven primarily by blue and red light absorption of cyanobacterial Chl. This explanation would account for the lack of spectral dependency on Chl-specific alphas in these surface samples (Fig. 8), whereby blue-green light absorbed by the blue Soret region of Synechococcus $\mathrm{Chl}$ is about as effective in driving carbon fixation as the tungsten 'white' light absorbed by the red Soret region of Synechococcus Chl (Boucher et al. unpubl.). Under such conditions, a spectral dependency in $\mathrm{P}_{\max }$ could result from an imbalance in the partitioning of absorbed light energy to Chls within photosytem I and II.

Synechococcus spp. numerically dominated ultraphytoplankton communities down to between 3 and $7 \% \mathrm{I}_{0}$, with maxima in cell abundance routinely located at $\geq 50 \% \mathrm{I}_{\circ}$ (Fig. 2). It was within these populations that blue-green light routinely provided much higher ( $\geq 5$-fold) estimates of light-limited rates of photosynthesis (alpha) than white light (Fig. 8). Concurrent with these observations, the PE content of Synechococcus cells increased with decreasing light and/or increasing nitrogen availability (Glover et al. $1988 \mathrm{~b})$, cells had a high ratio of phycourobilin to phycoerythrobilin chromophores (Campbell \& Iturriaga 1989) and cellular rates of Synechococcus photosynthetic performance were equally high from surface waters down to the maximum in PE concentrations (3 to $7 \% I_{0}$ ) (Prézelin \& Glover unpubl.). These observations suggest that photoadaptive increases in the content of blue-green light obsorbing $P E$ was central to the maintenance of high photosynthetic rates by Synechococcus populations throughout a large portion of the euphotic zone. The present study also documents that the observed increases in PE/cell occurred in direct proportion to blue-green light measurements of photo- synthetic quantum efficiency (Fig. 9), further indicating that these cyanobacteria are well suited to harvest the available light throughout a large portion of the euphotic zone. Hence, the color of the incubation light may be an important consideration in future studies aimed at determining the physiological bases of photosynthetic regulation in natural Synechococcus populations.

\section{Spectral effects on photosynthetic performance and contribution to primary productivity}

The present study emphasizes the comparison of photosynthic rates measured in size-fractions of communities incubated under tungsten 'white' or bluegreen spectral bands. However, we recognize that the base of the euphotic layer is dominated by blue-violet light ( 400 to $465 \mathrm{~nm}$ ), which enhances light absorption and photosynthetic quantum efficiency in a variety of ultraplankton algae (Prézelin \& Boczar 1986, Lewis et al. 1986, Glover et al. 1987). As a consequence, the present study may underestimate the productivity of eukaryotic algal communities and prokaryotic Prochlorophytes (Chisholm et al. 1987, 1988, Olson et al. 1988). Thus we are emphasizing Synechococcus spp., which dominated ultraphytoplankton communities from the surface down to depths just above the deep Chl maximum.

If the argument regarding the distinct nature of bluegreen light photophysiology of Synechococcus is accepted, then blue-green light or in situ estimates of primary productivity may be more accurate than 'white' light estimates and the former may provide a better basis to determine their contribution to total primary productivity in the open ocean. Since bluegreen light measurements tended to raise alpha and lower $I_{k}$ values, one impact on primary production estimates would probably come at depths where 'white' light measurements suggested light-limitation or photoinhibition. We observed that blue-green light incubations had the greatest impact on in situ productivity estimates just below the seasonal thermocline to the depth of the PE maximum (Figs. 10 and 11). Wavelength dependent effects on photosynthetic parameters were less evident within ultraphytoplankton communities at and below the Chl max, where phycobilin-rich organisms did not dominate and little difference in wavelength-dependent calculations of primary productivity were therefore found.

Since the blue-green light effects on individual size fractions tended to be greater than those expressed by the whole water sample, the percent contribution to total primary production by any fraction was also affected by the spectral quality of the incubation. A 
comparison of the estimated contribution of the 0.6-1 $\mu \mathrm{m}$ Synechococcus dominated fraction to whole water rates of in situ photosynthetic performance is summarized in Table 2. With increasing depth, there is a clear trend toward increased estimates of total primary production when blue-green rather than 'white' light conditions were used.

In conclusion, the color of the incubation light did not alter the timing of daytime variations in $\mathrm{P}_{\max }$ although there were occasions when color of the incubation light did affect the magnitude of $P_{\max }$ measured throughout the day. In contrast, alpha was often wavelengthdependent and the ratio of blue-green vs 'white' light alpha measurements could depend on the time of day that the measurement was made. In general, small daytime variations in $\mathrm{P}_{\max }$ combined with larger noncoincident changes in alpha gave rise to distinct diurnal patterns in $I_{k}$. The spectral dependency in $I_{k}$ estimates were clearly evident, with greatest changes in amplitude occurring in surface waters. It was the spectral dependency on alpha and $I_{k}$ that had the greatest impact on blue-green vs 'white' light estimates of in situ productivity, especially for Synechococcusdominated size fraction. However, the difference between blue-green and white light estimates of daily integrated rates of primary productivity were small since Synechococcus populations were localized in the upper part of the euphotic zone where photosynthesis was light-saturated throughout most of the day. While spectral dependency of Synechococcus photosynthesis did not impact greatly on the estimates of water column productivity, it was an important photophysiological consideration that linked the relative quantum efficiency of photosynthesis to the cellular concentrations of PE in natural populations of Synechococcus. The results showed that increases in the cellular content of $\mathrm{PE}$ in Synechococcus populations were central to maintaining high photosynthetic rates throughout most of the euphotic zone.

Acknowledgements. We acknowledge helpful discussions with R. Bidigare and R. Iturriaga and access to their data sets prior to publication. We thank W. Connely, A. Langeley, A. E. Smith and crew of the RV 'Endeavor' for assistance with measurements. R. Smith lent the spectroradiometer and C. Garside made inorganic nutrient measurements. This research was supported by NSF grants OCE 8521170 and OCE 8515738 awarded jointly to B. B. Prezelin and H. E. Glover.

\section{LITERATURE CITED}

Bidigare, R. R., Smith, R. C., Baker, K. S., Marra, J. (1987) Oceanic primary production estimates from measurements of spectral irradiance and pigment concentrations. Global biogeochem. Cycles 1: 171-186

Boussiba, S., Richard, A. E. (1980). C-phycocyanin as a storage protein in the blue-green alga Spirulina platensis. Arch Microbiol. 125: 143-147

Campbell, L., Carpenter, E. J. (1986). Diel patterns of cell division in marine Synechococcus spp. (Cyanobacteria): the use of the frequency of dividing cell technique to measure growth rate. Mar Ecol. Prog. Ser. 32: 139-148

Campbell, L. Iturriaga, R. (1988). Identification of Synechococcus spp. in the Sargasso Sea by immunofluorescence and fluorescence excitation spectroscopy performed on individual cells. Limnol. Oceanogr 33: 1196-1201

Carr, N. G., Wyman, M. (1986). Cyanobacteria: their biology in relation to the oceanic picoplankton. In: Platt, T., Li, W. K. (ed.) Photosynthetic picoplankton. Department of Fisheries and Oceans, Ottawa, p. 235-250

Chisholm, S. W., Olson, R. J., Zettler, E. R. (1987). Redfluorescing ultraplankton at the bottom of the euphotic zone: analysis by flow cytometry. EOS 68: 1706

Chisholm, S. W., Olson, R. J., Zettler, E. R., Goericke, R., Waterbury, J. B., Welschmeyer, N. A. (1988). A novel freeliving prochlorophyte abundant in the oceanic euphotic zone. Nature, Lond. 334: 340-343

Fogg, G. E. (1986). Picoplankton. Proc. R. Soc. (Ser. B) 228: $1-30$

Garside, C. (1982). A chemiluminescent technique for the determination of nanomolar concentrations of nitrate, nitrate and nitrite, or nitrite alone in seawater. Mar. Chem. 11: 159-167

Glover, H. E. (1985). The physiology and ecology of the marine cyanobacterial genus Synechococcus. In: Janasch, H. W., Williams, P. J. LeB. (eds.) Advances in aquatic microbiology. Academic Press, London, p. 49-107

Glover, H. E., Campbell, L., Prézelin, B. B. (1986). Contribution of Synechococcus to size-fractioned primary productivity in three water masses in the Northwest Atlantic Ocean. Mar. Biol. 91: 193-203

Glover, H. E., Keller, M. D., Spinrad, R. W. (1987). The effects of light quality and intensity on photosynthesis and growth of marine eukaryotic and prokaryotic phytoplankton clones. J. exp mar. Brol. Ecol. 105: 137-159

Glover, H. E., Prézelin, B. B., Campbell, L., Wyman, M., Garside, C. (1988a). A nitrate-dependent Synechococcus bloom in surface Sargasso Sea water Nature, Lond. 331: 161-163

Glover, H. E., Prézelin, B. B., Campbell, L., Wyman, M. (1988b). Pico- and ultra-plankton Sargasso Sea communities: variability and comparative distributions of Synechococcus spp. and algae. Mar. Ecol. Prog. Ser. 49: $127-139$

Iturriaga, R., Marra, J. (1988). Temporal and spatial variability of chroococcoid cyanobacteria, Synechococcus spp., specific growth rates and their contribution to primary production in the Sargasso Sea. Mar. Ecol. Prog. Ser. 44: $175-181$

Jerlov, N. G. (1976). Marine optics. Elsevier, Amsterdam, p. 418

Joint, I. R. (1986). Physiological ecology of picoplankton in various oceanographic provinces. In: Platt, T., Li, W. K. W. (eds.) Photosynthetic picoplankton. Can. Bull. Fish. Aquat. Sci. 214: 287-309

Kiefer, D., Strickland, J. D. H. (1970). A comparitive study of photosynthesis in seawater samples incubated under two types of light attenuator. Limnol. Oceanogr. 15: 408-412

Lewis, M. R., Smith, J. C. (1983). A small-volume, shortincubation time method for the measurement of photosynthesis as a function of incident irradiance. Mar. Ecol. Prog. Ser. 13: 99-102

Lewis, M. R., Ulloa, O., Platt, T (1988). Photosynthetic action, 
absorption, and quantum yield spectra for a natural population of Oscillatoria in the North Atlantic. Limnol. Oceanogr. 33: 92-98

Lewis, M. R., Warnock, R. E., Platt, T (1986). Photosynthetic response of marine picoplankton at low photon flux. In: Platt, T., Li, W. K. W. (eds.) Photosynthetic picoplankton. Can. Bull. Fish. Aquat. Sci. 214: 235-250

Li, W. K. W (1986). Experimental approaches to field measurements. In: Platt, T., Li, W. K. W. (eds.). Can. Bull. Fish. Aquat. Sci. 214: 251-286

Li, W. K. W., Platt, T. (1987). Photosynthetic picoplankton in the ocean. Sci. Prog. Oxf. 71: 117-132

Li, W. K. W., Wood, A. M. (1988). Vertical distribution of North Atlantic ultraphytoplankton: analysis by flow cytometry and epifluorescence microscopy Deep Sea Res.

Malone, T (1980). Algal size. In: Morris, I. (ed.) The physiological ecology of phytoplankton. Univ, of California Press, Berkeley, p. 433-464

Marra, J., Heinemann, K. R. (1987). Primary production in the North Pacific Central Gyre: some new measurements based upon ${ }^{14} \mathrm{C}$. Deep Sea Res. 34: 1821-1829

Murphy, L. S., Haugen, E. M. (1985). The distribution and abundance of phototrophic ultraplankton in the North Atlantic. Limnol. Oceanogr. 30: 47-58

Olson, R. J., Chisholm, S. W., Zettler, E. R., Armbrust, E. V. (1988). Analysis of Synechococcus pigment types in the sea using single and dual beam flow cytometry. Deep Sea Res. 35: $425-440$

Olson, R. J., Vaulot, D., Chisholm, S. W. (1985). Marine phytoplankton distributions measured using shipboard flow cytometry. Deep Sea Res. 32: 1273-1280

Powles, S. B. (1984). Photoinhibition of photosynthesis induced by visible light. In: Briggs, $W$ R., Jones, R. L., Walbot, $V$ (ed.) Annual review of plant physiology, Vol. 35. Annual Reviews Inc., Palo Alto, p. 15-44

Prézelin, B. B., Baker, K. S., Bidigare, R. R., Smith, R. C. (1987a). Bio-optical modeling of a coastal front. XIX General Assembly, International Union of Geodesy and Geophysics, Univ. British Columbia, Vancouver, B.C., Canada

Prézelin, B. B., Bidigare, R. R., Matlick, H. A., Putt, M., Ver Hoven, B. (1987b). Diurnal patterns of size-fractioned primary productivity across a coastal front. Mar. Biol. 4: $563-574$

Prézelin, B. B., Boczar, B. A. (1986). Molecular bases of cell absorption and fluorescence in phytoplankton: potential

This article was submitted to the editor applications to studies in optical oceanography. Prog. phycol. Res. 4: 350-464

Prézelin, B. B., Glover, H. E., Campbell, L. (1987c). Effects of light intensity and nutrient availability on diel patterns of cell metabolism and growth in populations of Synechococcus spp. Mar. Biol. 95: 469-480

Prézelin, B. B., Putt, M., Glover, H. E. (1986). Diurnal patterns in photosynthetic capacity and depth-dependent photosynthesis-irradiance relationships in Synechococcus spp. and larger phytoplankton in three water masses in the Northwest Atlantic Ocean. Mar. Biol. 91: 205-217

Putt, M., Prézelin, B. B. (1985). Observations of diel patterns of photosynthesis in cyanobacteria and nanoplankton in the Santa Barbara Channel during 'El Niño'. J. Plankton Res. 6: 779-790

Shapiro, L. P., Guillard, R. R. L. (1986). Physiology and ecology of marine eukaryotic ultraplankton. In: Platt, T., Li, W. K. W (eds.) Photosynthetic picoplankton. Can. Bull. Fish. aquat. Sci. 214: 371-389

Smith, R. C., Bidigare, R. R., Prezelin, B. B., Baker, K. S. Brooks, J. M. (1987). Optical characterization of primary productivity across a coastal front. Mar. Biol. 96: 575-591

Strickland, J. D. H., Parsons, T R. (1972). A practical handbook of seawater analysis, 2nd edn. Fish. Res. Bd Can. Bull. 167

Sweeney, B. M., Borgese, M. B. (1988). A circadian rhythm in cell division in a prokaryote, the cyanobacterium Synechococcus NAG, strain WH7803. J. Phycol. (in press)

Takahashi, M., Bienfang, P. K. (1983). Size structure of phytoplankton biomass and photosynthesis in subtropical and tropical Hawaiian waters. Mar. Biol. 76: 203-211

Thomsen, H. A. (1986). A survey of the smallest eucaryotic organisms of the marine phytoplankton. In: Platt, T, Li, W K. W. (eds.) Photosynthetic picoplankton. Can. Bull. Fish. aquat. Sci. 214: 121-158

Waterbury, J. B., Watson, S. W., Valois, F. W., Frank, D. G. (1986). Biological and ecological characterization of the marine unicellular cyanobacterium Synechococcus. In: Platt, T., Li, W. K. W. (eds.) Photosynthetic picoplankton. Can. Bull. Fish. aquat. Sci. 214: 71-120

Wood, A. M. (1985). Adaptation of photosynthetic apparatus of marine ultraphytoplankton to natural light fields. Nature, Lond. 316: 253-255

Wyman, M., Gregory, R. P. F., Carr, N. G. (1985). Role of phycoerythrin in marine Synechococcus strain DC-2. Science 234: 1423-1424

Manuscript first received: October 26, 1988 Accepted: February 20, 1989 